\title{
PATELLA FUSCA.
}

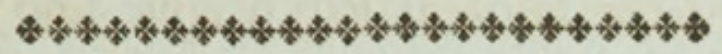

\section{CHARACTER GENERICUS.}

Animal Limax.

Testa univalvis, subconica, absque spira.

Lin. Syst. Nat. p. 1257.

CHARACTER SPECIFICUS, EC.

PATELLA testa subintegra ovata obtusa fusca, elevato-striata, intus alba.

PATELLA FUSCA. P. testa integerrima ovata, obtusa, striis elevatis.

Lin. Syst. Nat.

Maria Indica et Americana incolit Patella fusca, magnitudine vera in tabula depicta. 


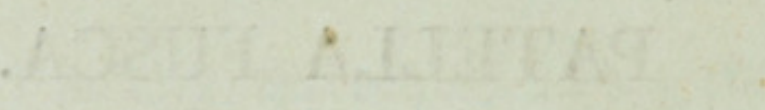

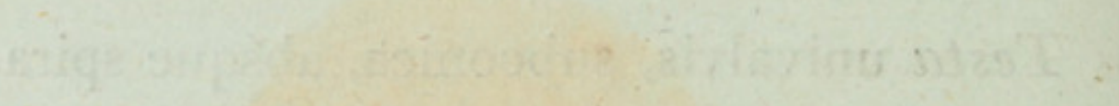

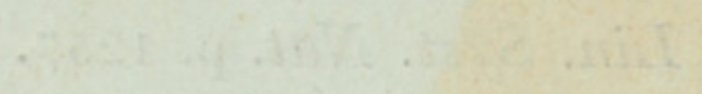

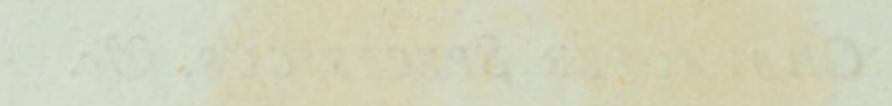

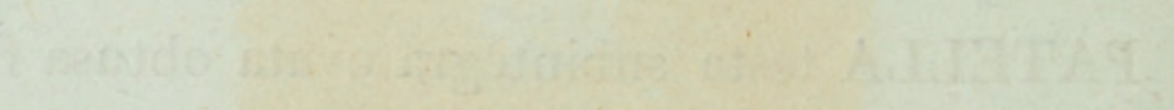

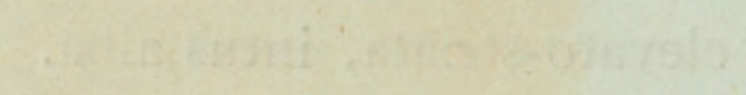

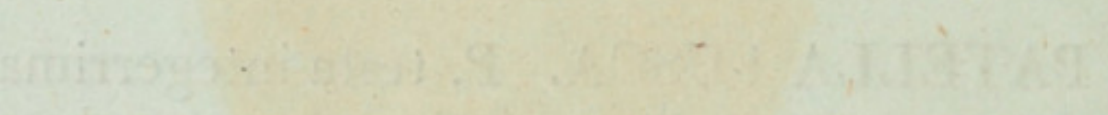

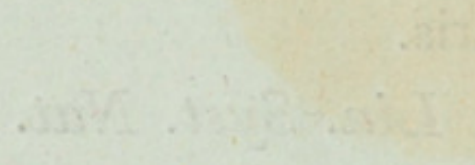


606
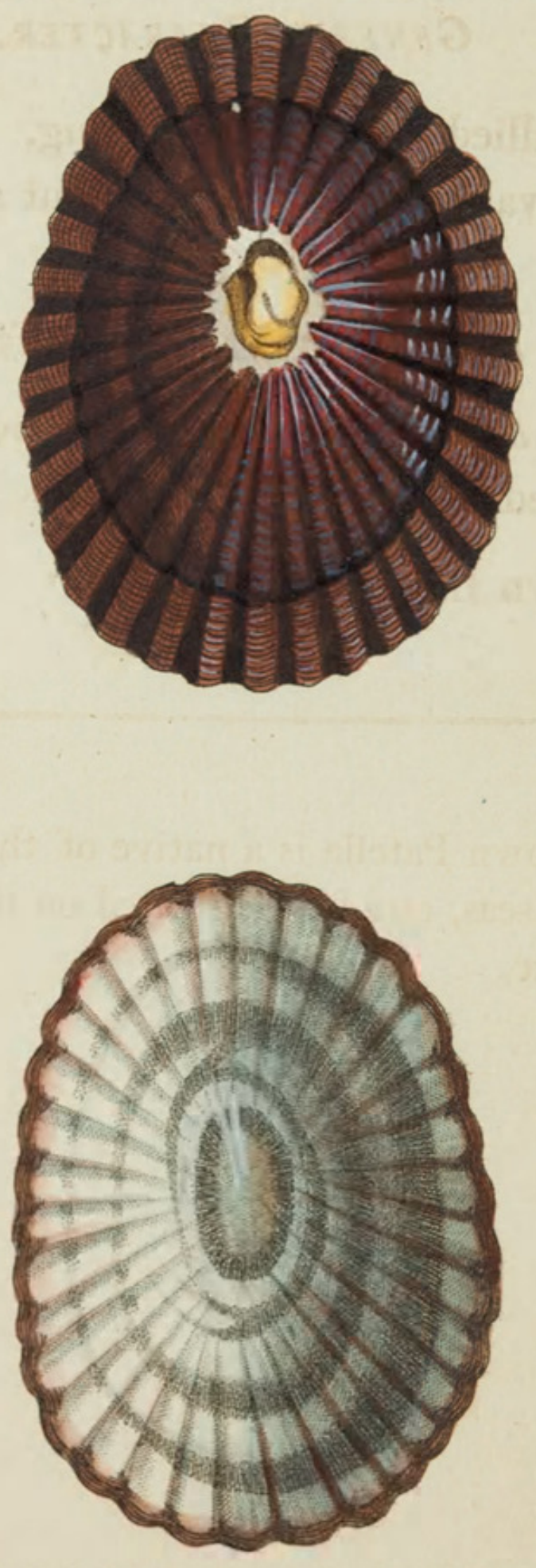

aqu 


\section{THE \\ BROWN PATELLA.}

눈

\section{GENERIC CHARACTER.}

Animal allied to a Limax or Slug. Shell univalve, 'subconic, without spire.

\section{SPECIFIC CHARACTER, EंC.}

PATELLA with nearly entire, ovate, brown, ribbed Shell, white within.

The brown Indian Limpet.

The Brown Patella is a native of the Indian and American seas, and is represented on the plate in its natural size. 


\section{$2 \mathrm{BHL}$ Biodiversity Heritage Library}

Shaw, George. 1804. "The Brown Patella, Patella fusca [PI. 606]." The Naturalist's Miscellany 15(CLXXIII), https://doi.org/10.5962/p.311049.

View This Item Online: https://www.biodiversitylibrary.org/item/280634

DOI: https://doi.org/10.5962/p.311049

Permalink: https://www.biodiversitylibrary.org/partpdf/311049

\section{Holding Institution}

Museums Victoria

\section{Sponsored by}

Atlas of Living Australia

\section{Copyright \& Reuse}

Copyright Status: Public domain. The BHL considers that this work is no longer under copyright protection.

This document was created from content at the Biodiversity Heritage Library, the world's largest open access digital library for biodiversity literature and archives. Visit BHL at https://www.biodiversitylibrary.org. 